Article

\title{
The Great Secession: Ethno-National Rebirth and the Politics of Turkish-German Belonging
}

\author{
Özgür Özvatan
}

Berlin Institute for Integration and Migration Research, Humboldt University of Berlin, 10099 Berlin, Germany; E-Mail: oezguer.oezvatan@hu-berlin.de

Submitted: 31 August 2019 | Accepted: 25 February 2020 | Published: 25 March 2020

\begin{abstract}
Germany is facing a contemporary mainstreaming of the far right, which has a long tradition of wanting "Turks out!" Turkish immigrants have been the main strangers in Germany following the guest-worker treaty signed in 1961, physically close as friends, yet culturally distant as foes. From September 2015 onwards, German-Turkish politics of belonging, the Turkish issue, underwent a contentious period resulting in secessions between German and Turkish authorities in September 2017. Against this background, this article asks: How did mainstream political actors in Germany emplot the Turkish issue while a far-right challenger party sought to establish a far-right narrative of ethno-national rebirth? The temporal unfolding of the Turkish issue is explored by drawing on media analysis $(n=1120)$, interpretive process-tracing and narrative genre analysis of claims raised by political actors in German and Turkish newspapers. In order to visualize how the Turkish issue evolved between 2000 and 2017 in media discourse, 546 articles in the mainstream quality newspaper Frankfurter Allgemeine Zeitung were collected. The Great Secession period between 2015 and 2017 was selected for an in-depth case study. To conduct interpretive process-tracing and narrative genre analysis of this case, another 574 articles in the German Süddeutsche Zeitung and Turkish Hürriyet were analysed. In so doing, this article contributes to (1) the study of belonging and identity by adopting a novel approach to boundary studies, combining narrative genre analysis with Habermas' communicative action theory, and (2) the study of political strategies of adapting, ignoring or demarcating far-right contenders by, again, introducing a narrative approach to political communication and mobilization processes. The analysis shows that, in the first stage of the Great Secession period, inclusionary and exclusionary boundaries competed, while in later stages inclusionary boundaries were cast aside by exclusionary boundaries after reputable mainstream party-political actors adopted and thus legitimized far-right story elements.
\end{abstract}

\section{Keywords}

belonging; boundary studies; exclusion; far right; Germany; identity; immigrant integration; inclusion politics; narrative theory; Turkey

\section{Issue}

This article is part of the issue "Boundary Spanning and Reconstitution: Migration, Community and Belonging" edited by Anya Ahmed (University of Salford, UK).

(C) 2020 by the author; licensee Cogitatio (Lisbon, Portugal). This article is licensed under a Creative Commons Attribution 4.0 International License (CC BY).

\section{Introduction}

The Turkish minority in Germany serves as a well-fitting example of Simmel's concept of the stranger: physically close as friends, yet culturally distant as foes (Kaya, 2018). The German magazine Der Spiegel reported former topsecret British documents recording talks between thenChancellor Helmut Kohl (Christlich Demokratische Union Deutschlands, hereafter CDU) and Margaret Thatcher which reveal his ambition in the 1980s to halve the size of Germany's Turkish population because of alleged "cultural incompatibilities." Indeed, his government introduced a return programme for Turkish guestworkers in 1983, which contained financial incentives to encourage them to return (Hecking, 2013). This alleged strangeness has affected millions of people, although there have been times when Turkey and Germany showed close connections at the turn of the previous cen- 
tury (Neumann, 1999), and has endured since Germany and Turkey signed the guest-worker treaty in 1961. Today, roughly 3 million Turkish immigrants live in Germany and challenge regulations of membership and belonging (Mandel, 2008). In 2000, German citizenship laws were liberalized towards naturalisation and dual citizenship. Since 2008, claiming to help sustain the Turkish diaspora's Turkish cultural identity (e.g., "assimilation is a crime against humanity"), Turkish President Erdoğan regularly aimed to (re-)vitalize the Turkish issue in Germany. Interestingly, German politics remained unresponsive to Erdoğan's politicisation until 2015. Drawing on quantitative data, this article explores how German politics became responsive to such politicization and, drawing on media analysis, how the politics of Turkish-German belonging unfolded from September 2015 onwards, facilitating a secessionist outcome in September 2017, with formerly consensus-oriented German chancellor Merkel now breaking ties with Turkish politics.

The Turkish issue is defined as a political discourse that emerges in the realm of Turkish-German politics of belonging between Germany, Turkey and the Turkish diaspora. It is enacted by political actors who raise political claims embedded in wider narratives of people making sense of the world. In this respect, political actors in Germany and Turkey discursively construct the Turkish issue through conflicts in politics of belonging. Narratives serve a crucial social function to the politics of belonging. They interpellate subjectivities (social roles) by foregrounding certain events and backgrounding others in a meaningful storyline through which social boundaries of "us" and "them" emerge. In (Western) literature theory, such narratives are typically organized in four genres: romance, comedy, tragedy and irony (Frye, 1957). Comedies and romances are characterized by happy endings for a self-sufficient and pure "us." Communication flows remain within the self-centred conclusive boundaries of "us," the stranger is excluded from open and egalitarian communication processes (i.e., democratic debate). Tragedy and irony, in contrast, facilitate open communication processes that foster the inclusion of "new" or dissimilar perspectives (i.e., the stranger's perspective) on the basis of self-decentred and inconclusive social boundaries (Forchtner, Engelken Jorge, \& Eder, 2018).

Against this background, this article asks: How do German mainstream parties emplot their stories in politics of Turkish-German belonging vis-à-vis a rising farright contender? Germany is alleged to face a contemporary "normalisation" of the far right (Quent, 2019), and the rise of populist far-right actors also accounts for a wider continental Europe (van Kessel, 2015). The German far right has a long tradition of wanting "Turks out!" This was a famous campaign slogan of the German Nationaldemokratische Partei Deutschlands (hereafter NPD) party in the early 1990s when Turkish immigrants were victims of several racist terrorist attacks, and its ethno-religious blending with Islam was recently loudly voiced by the Alternative für Deutschland (hereafter AfD) party (Özvatan \& Forchtner, 2019). Research finds there are contagious (Akkerman, de Lange, \& Rooduijn, 2016; van Spanje, 2010) or modest (Dancygier \& Margalit, 2019) effects of radical-right anti-immigration positions on the mainstream, while these studies of party positions fall short of exploring the deeper-level effects on the political centre. That is, do far-right challengers succeed in pushing for the adaptation of "their" narratives by the political centre? Thus, this article more precisely asks: How do mainstream political actors emplot (i.e. sustain or modify) their stories in politics of TurkishGerman belonging while an uprising far-right challenger party seeks to establish a far-right narrative of ethnonational rebirth?

The two-year period from September 2015 to September 2017, which I call the Great Secession, was selected for an in-depth case study of the Turkish issue, for which 574 articles in the cross-nationally comparable centrist quality newspaper German Süddeutsche Zeitung and Turkish Hürriyet were amassed. To understand how the Turkish issue arrived at a secessionist outcome, the temporal unfolding of stories is explored by drawing on interpretive process tracing and narrative genre analysis of political actors' statements in these newspapers. This case selection is backed by three empirical findings: (1) The media analysis of 546 articles in Frankfurter Allgemeine Zeitung (FAZ) between 2000 and 2017 points to the increasing salience of the Turkish issue between September 2015 and September 2017, (2) immigrationrelated political concerns prevail in the German public sphere from late 2014 onwards (Forschungsgruppe Wahlen, 2019), and (3) the electoral successes of the German AfD party. The Great Secession period was subdivided into three stages to trace how stories, story elements and boundaries transformed during that period. In so doing, this article shows that, in the first stage of the Turkish issue, stories fostering inclusionary and exclusionary social boundaries competed for hegemony, while in later stages exclusionary ethno-cultural boundaries prevailed after reputable mainstream actors had adopted and thus legitimized self-centring and definite stories of "us" and "them."

By adopting a novel approach to boundary dynamics, a revised Habermas-inspired storytelling framework, this article contributes to the study of politics of belonging, social boundaries and collective identity. The inclusion of "new" political subjects is more than the argumentative bridging of perspectives under the condition of mutual recognition as legitimate speakers (Verständigung; see Habermas, 1981, 1998). As Forchtner et al. (2018) have convincingly argued, argumentation alone does not cover the richness of social life, and thus the narratively structured lifeworld context has to play a conceptually more central role. Consequently, the focus needs to be shifted from argumentation to storytelling in order to examine boundary dynamics in greater depth, i.e., to make sense of how social boundaries span and close. Following the argumentation line that some story 
genres (comedy and romance) instil self-centred and definite boundaries, and others self-decentred provisional boundaries (irony and tragedy), I argue that this Habermasian-inspired storytelling approach marks a key site for assessing inclusionary and exclusionary politics of Turkish-German belonging.

In the next section, key theoretical concepts in studies on national belonging and social boundaries are introduced. In Section 3, I propose the narrative boundary model as an extension to the literature on boundary studies. In Section 4, the within-case selection of the Great Secession period is justified, and narrative boundary analysis is applied to its three stages. A discussion of and conclusion to the narrative boundary analysis of the Turkish issue are presented in Section 5.

\section{Barriers to the National Homeland: Contestations over Belonging and Its Boundaries}

Recent developments in the research on nationalism move beyond hard facts, they include rather soft, yet just as influential parameters such as symbolic structures and feelings to make sense of national belonging and its boundaries. In her seminal work, Nira Yuval-Davis (2011, p. 35) defines belonging thus: "[It] is about feeling "at home," feeling "safe," and if not necessarily feeling in control, at least feeling able enough generally to predict expectations and rules of behaviour." Although this definition stresses the role of a "safe home," it embraces inclusionary and exclusionary stories of national belonging, thus covering political subjectivities which participate in a constant process of (re-)production of cultural identity and belonging (Hall, 1996).

Immanent to the analysis of symbolic social boundaries is an exploration of who is defined as inside and outside a given society or community (Lamont \& Molnár, 2002). The imaginary of a national homeland constitutes such a community of us (Anderson, 1983), a national social order built on the ideals of purity and clarity which seeks to eradicate ambivalence, danger and pollution (Bauman, 1991; Douglas, 1966). It seems essential to clarify at this point that symbolic boundaries do not imply or refer to actual (i.e., material) social boundaries or actual strategies of action more generally. As Hall and Lamont (2013, p. 56) note, one can describe symbolic boundaries through the concept of cultural repertoires, which "are the sets of ideas, stories, discourses, frames, and beliefs that people draw on to create a line of action in the first place." A social order materializes its structures following meaningful symbols embedded in the stories people tell to make sense of the world. For instance, "free body culture" (Freikörperkultur) serves a cultural repertoire of "liberal" German ethno-national traditions embedded in the (Western) rational Enlightenment narrative, which may serve as a mobilising element according to which "true" Germans oppose the Muslim headscarf (as a sign of female oppression) in order to sustain "our" free ethno-national way of living.
Research shows that the constitution of ethnic group boundaries is a reciprocal process between social groups (e.g., Barth, 1969). Barth argues that, in this process, social groups develop a collective consciousness of forming a socially connected group based on sameness including a boundary drawn to demarcate dissimilar "others." Others have theorized the making of these ethnic boundaries by distinguishing between thick/hard and thin/soft boundaries (e.g., Wimmer, 2013; for a related intersectional account see Choo \& Ferree, 2010). However, the mechanisms of ethnic boundary transformation from "static being" to "fluid becoming" remain under-researched in the literature. For example, Alba (2005) explores the static production of blurry or bright boundaries, yet there is rare theorisation of fluid becoming of boundaries, i.e., how a bright ethnic boundary blurs over time or vice versa. Korteweg and Yurdakul (2014) fill this niche when identifying one such mechanism of boundary-blurring in their comparative analysis of the headscarf debate: Established host-society political actors must politicize established boundaries of (ethno-)national belonging in order for marginalized immigrant political actors to blur those boundaries in the public discourse. In the next section, I propose a theoretical model to systematically analyse the fluid becoming of boundaries over time, that is, their brightening and blurring.

\section{The Narrative Boundary Model: Stories, Genres and Belonging}

In western societies, political parties engage in tamed communication processes characterized by argumentative debate, though this evolves within a narratively structured world. This means that beneath argumentation lies a narrative (genre) which stories actors, events and boundaries (Forchtner, 2016; Forchtner et al., 2018). Because of the storytelling foundation of political communication, I define the politics of belonging as a political drama that includes cultural performances, such as crafting stories that create meaningful events, subjectivities and boundaries. Political parties' performativity lies in crafting stories; they enact political dramas through which they seek to amplify popular resonances with the masses. As such, political dramas may or may not resonate with the (cultural) stories of the masses ("fusion" or "de-fusion" respectively; see Alexander, 2004). If an ingroup story fuses, affected members of the group experience emotions associated with a given narrative genre: They recognize a plot, identify with "our" hero(ine) and live the "feelings" provided by the plotline and the story resolution (Forchtner, 2016; Wagner-Pacifici, 1986).

Adding narrative theory to Habermas' theory of communicative action, the narrative boundary model defines the story genre as a key mechanism of explaining the (un-)certainty of the resulting boundary type disseminated in political dramas. I shall argue that tragic and ironic stories facilitate spanning social boundaries, while 
comic and romantic stories draw rigid and conclusive social boundaries.

A well-established definition for narrative from Toolan $(1988$, p. 6) postulates that "narrative is a perceived sequence of non-randomly connected events." His definition emphasizes the role of temporality and meaning-making for the non-randomized connection of events. Meaning arises through creating a line of action by back-and foregrounding certain events. Thus, narratives lend meaning to human experiences over time (see also Bruner, 2004). The narrating human species stories its experiences in an event-based, sequential order. Collective identities built on that narrative scheme. They link storied projections of the past, present and future in a narratively meaningful way to create a sense of commonality and belonging (Somers, 1994).

The prevailing four narrative genres in Western literature are romance, comedy, tragedy and irony (Frye, 1957; White, 1973). Genres have unique plot lines that connect events in a narratively meaningful order (Figure 1). As Figure 1 illustrates, plot lines are shaped by the combination of two dimensions: the moral evaluation of an event as positive $(+)$ or negative $(-)$ and time $(t)$.

To illustrate the former, Romeo and Juliet fall in love at the beginning of the drama before the audience gets to know the problematic background information. The moral evaluation at that specific temporal point of the story is heart-warming. Frye (1957, p. 162) argues that the positive $(+)$ and negative (-) spheres reflect twolevel imaginaries of the world, the ideal and the actual, respectively. Plots in the lower half reflect the unidealized actual world (-), which is an analogy of realism and experience, i.e., the complexity, conflict and am- bivalence of the world, while plots in the upper half, the world of idealized existence, represent romance and innocence (+), i.e., storied phantasies of homogeneity, unity and purity in the world.

The second dimension, time, covers the sequential organisation of events through narrative. Usually, stories are emplotted in three stages: the introduction of the protagonists in the beginning, the middle stage in which a problem emerges, and the ending in which the problem is resolved or not, which is commonly defined as the story resolution. Wagner-Pacifici (1986, p. 282) argues that in order to control the cultural meaning of a given story, one has to control its ending, i.e., its resolution. In fact, comedy and romance share a problem for the social order being resolved with a happy ending, which renders feelings of unity and self-sufficiency. Romantic plot lines steadily climb to a heart-warming happy ending, while comic plotlines sharply ascend from a downturn sequence to a joyful happy ending (see Figure 1). Their plotlines slightly differ though: Romantic downturns are less tragic, they remain in the sphere of idealized existence, whereas comic deep downturns descend into the intricacies of the unidelized actual world, which makes the hero(ine) face a catastrophe before a sharp ascent to the ideal world results in a "new-born society rising in triumph" (Frye, 1957, p. 192). Because the sharp ascent releases accumulated tensions, festive celebrations (e.g., fireworks, wedding, etc.) commonly feature comedy's happy ending.

Tragic and ironic stories lack joyful, reassuring story resolutions. In a tragedy, the tragic hero(ine) fails, in a series of events (e.g., rescuing attempts), to hinder an inescapable cathartic ending. The hero(ine) torturously
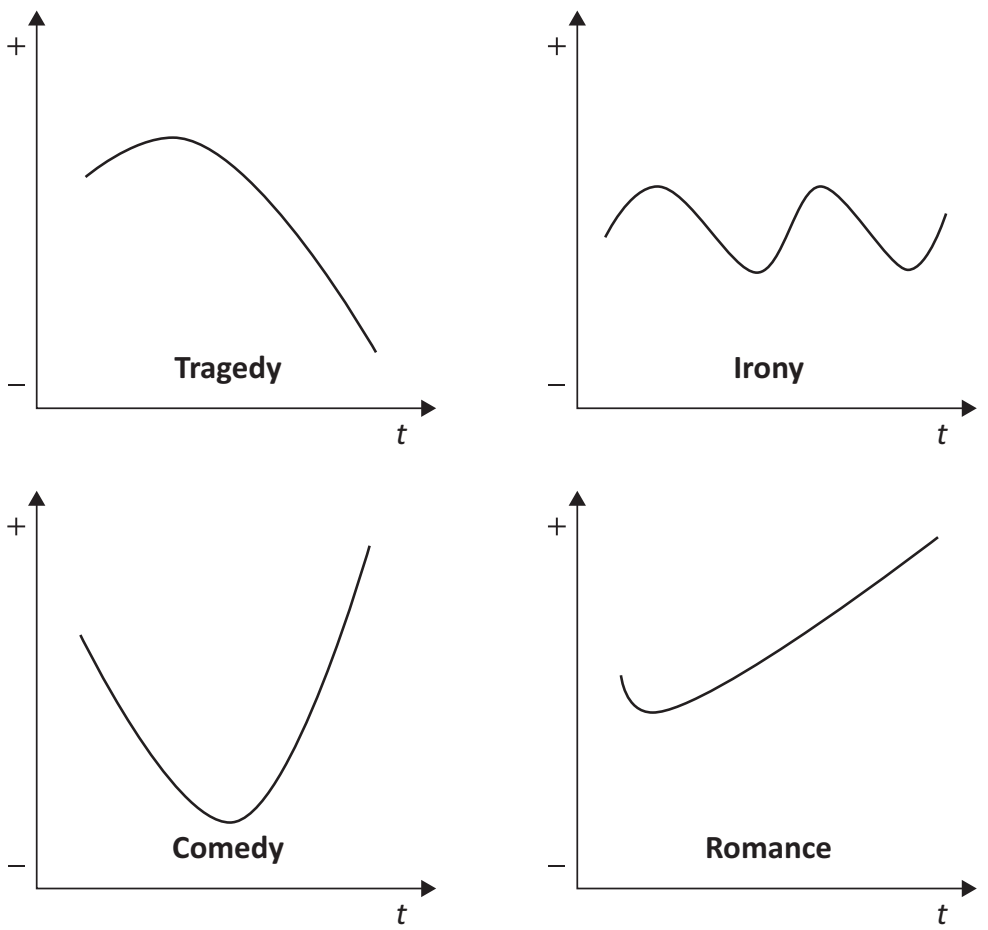

Figure 1. Schematic representation of narrative genre plot lines (own visualisation). 
learns that $s($ he) is not self-sufficient, unable to solve the intruding problems. In the literature, irony is not assigned a specific storyline; Frye (1957, p. 223) defines irony as "the parody of romance." He understands an idealized form of irony, militant irony, as just another form of comedy or romance that generates idealized selfreassuring romanticism by parodying others. One way of interpreting Frye's definition of irony is to speak of selfirony. Self-irony attempts "to give form to the shifting ambiguities and complexities of unidealized existences" (Frye, 1957, p. 223). That is, by means of continuous selfreflexive distancing from previously held sets of beliefs, self-irony is marked by "the sense that heroism and effective action are absent, disorganized or foredoomed to defeat, and that confusion and anarchy reign over the world" (Frye, 1957, p. 192). Since the distancing from an idealized existence marks the nature of (self-)irony, the plot line travels continuously between the idealized world and the unidealized actual world. The hero(ine) is never self-sufficient but constantly in need of debate and renegotiation, i.e., inclusive democratic deliberation.

Political parties are mobilizing storytellers likely to narrate comic plots. They claim that, with their help, society will overcome an imminent challenge and celebrate "the new-born society rising in triumph" (Frye, 1957, p. 192); Trump's campaign slogan "Make America Great Again!" is a case in point. However, in the empirical world, narrative genres rarely occur in pure form. Storytellers instil story elements of other genres into their plots (Engelken Jorge, Forchtner, Eder, \& Özvatan,
2019; Özvatan \& Forchtner, 2019). Indeed, Özvatan and Forchtner (2019) illustrate that the German AfD party increasingly implements romance into its comedy, which is the evermore radicalising promise of an ethno-national rebirth for "true" Germans defined by ethno-racial ancestry/destiny.

Figure 2 represents the link between narrative genres and social boundaries. This model contains two dimensions: the purity/impurity of the hero(ine) and the restrictiveness/expansion of the discursive space. Jointly, both dimensions explain the certainty-uncertainty continuum of the imaginary of social boundaries (dotted diagonal line). The (im-)purity dimension refers to projected positive/negative images of the story's hero(ine). If the hero(ine) is portrayed as self-sufficient, $s($ he) is pure and vice versa. The (im-)purity of the hero(ine) relates to the discursive space too: If the story resolution's projected hero(ine) is self-sufficient/pure, the discursive space for debating further steps shrinks. Thus, it appears redundant to debate further steps when the hero(ine) is capable of resolving an emerging problem satisfactorily. In turn, the discursive space expands if the hero(ine) is impure and not self-sufficient. The unsolved (or unsolvable) problem triggers a need to foster communication processes, that is, debate further steps to be taken.

The interaction of both dimensions determines the (un-)certainty of imagined social boundaries: (1) If the hero(ine) is pure and the discursive space shrinks, the certainty of the social boundary is high; in turn, (2) if the hero(ine) is impure and the discursive space ex-

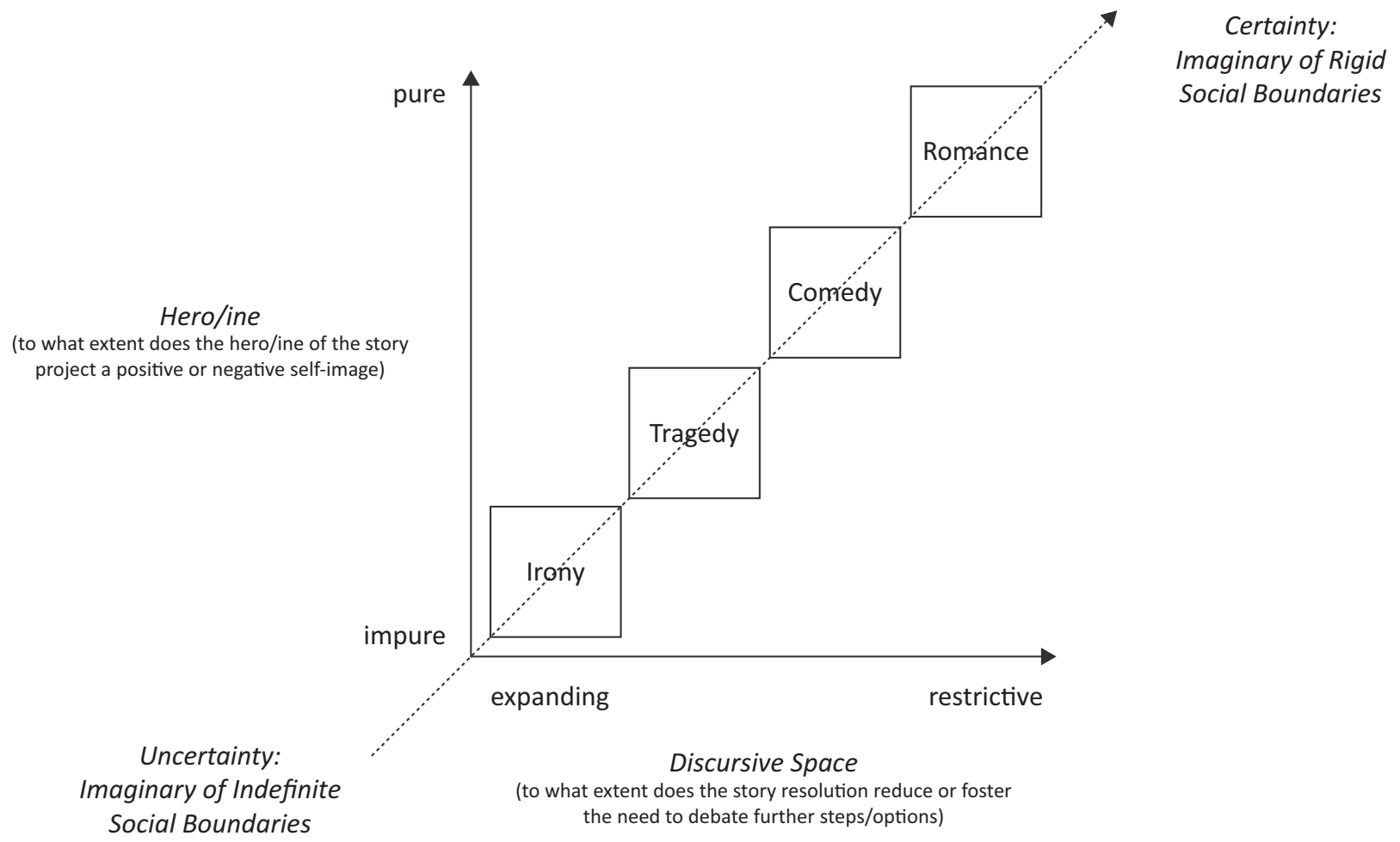

Figure 2. Schematic representation of the link between narrative genres and social boundaries (a modified version of the model proposed by Forchtner et al., 2018, p. 12). 
pands, the uncertainty of the social boundary is high. The self-sufficiency of pure hero(in)es renders conclusiveness and certainty to social boundaries. Social boundaries become uncertain through the inconclusiveness of a story. The potential for including "new" or dissimilar perspectives rises as the story resolution's lesson tells us that our hero(ine) is not capable of solving the problem without including the perspectives of others into communication processes.

Put together, rigid social boundaries are fostered by romance and comedy, while tragedy and irony allow for indefinite/blurry social boundaries (Figure 2). In a romance, "the good guys are clearly good from the outset: they wear the white hats while the bad guys wear the black hats" (Wagner-Pacifici, 1986, p. 282). The unquestioned purity and self-sufficiency of "the good guys with the white hats" prove that they are the only legitimate interlocutors in a democratic debate. Jacobs and Smith (1997, p. 68), for instance, argue that "nationalist ideology is built upon the Romantic narrative of a 'national' community with a distinct and ascending destiny." Comic stories are less restrictive than romances, the composition of the "good guys" may expand or shrink after the reunification or reconciliation process. However, the certainty of social boundaries rises following a unifying happy ending. The "national" community is put back on the right track, including a redefinition of who is part of the common "ascending destiny." In the absence of ironic elements, it seems unlikely that the membership criteria of the "national" community are extended to "others." In a tragedy, the hero(ine) is snared in a noway-out dilemma. To protect us from future tragedies, communication processes may transcend social boundaries and include "new" or dissimilar perspectives. Irony is the only genre that lacks a genuine plot line. This genre is characterized by the hero(ine)'s distancing from established commonalities such as, for instance, a common ethno-racial destiny. Such distancing from notions of an essentialized and self-reassuring community fosters open communication processes, which is a condition for boundary-spanning and the inclusion of others.

In order to operationalize the linkage of narrative genres and social boundaries for the empirical analysis, I draw on three social boundary types postulated by Yuval-Davis (2011, p. 21). The first is the racialized boundary, which fabricates impenetrable boundaries through ascriptive markers, i.e., ethnic origin, "race" and place of birth. The second is the cultural boundary, building on language, culture and sometimes religion, which may depend on "the other's" assimilatory efforts to acquire a host society culture (language, culture or religion) and, generally, involves a tedious process. The third is the civic boundary, which understands belonging on the basis of civic values such as "human rights" or "democracy," e.g., Habermas' prominent notion of Verfassungspatriotismus, which marks normative ideals formulated in the constitution as nodal points for membership and boundaries.

Figure 3 is a schematic representation of where the three social boundary types are located in the narrative boundary model. Given that political parties narrate comic plots combined with elements of other genres, here I will describe the embeddedness of the three boundary types in primarily comic stories. That is, I shall

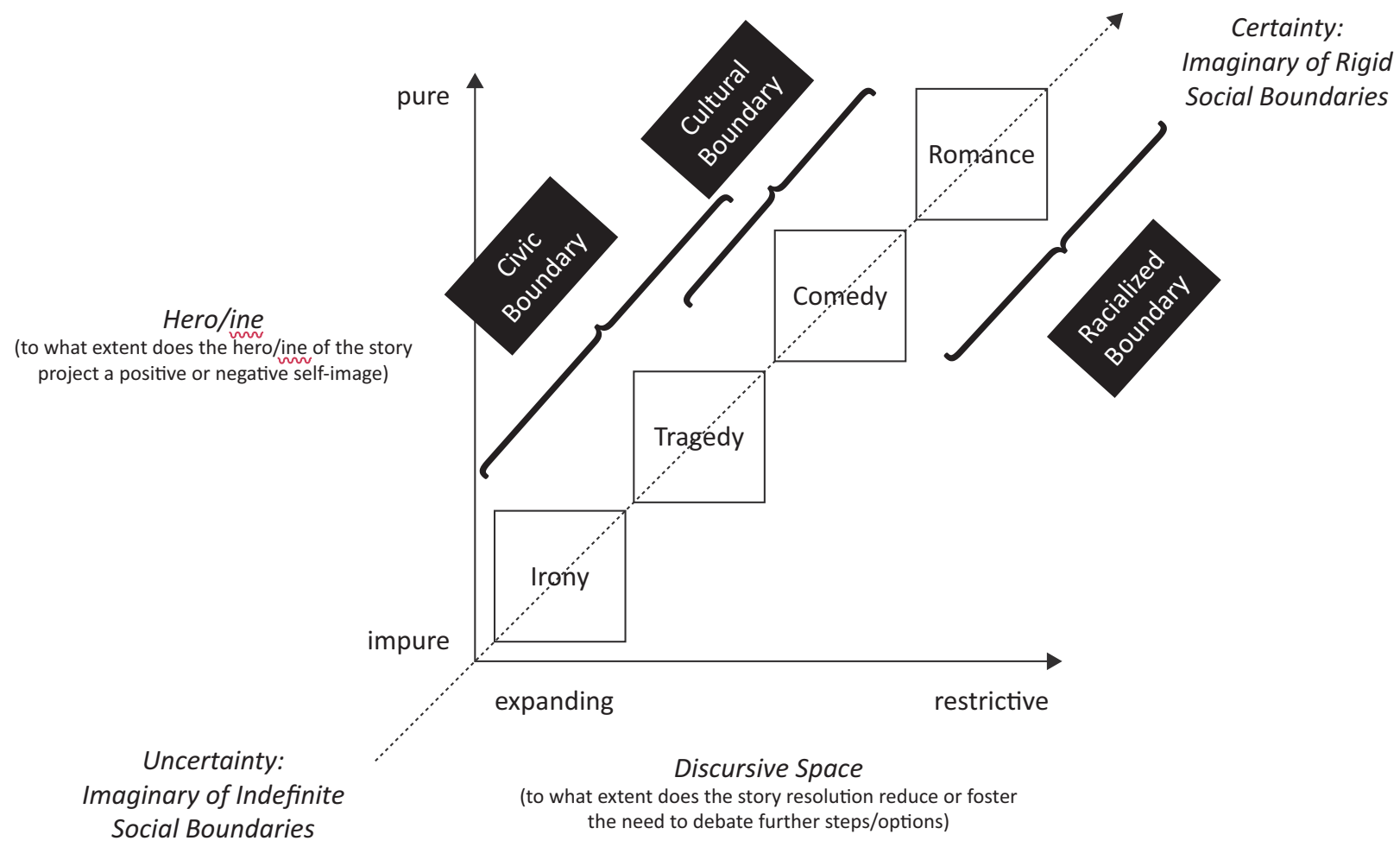

Figure 3. Schematic representation of the link between narrative genres and social boundary types (own visualisation). 
illustrate in which directions the storied comedies move on the uncertainty-certainty continuum. The more idealized ancestral elements (i.e., romantic elements) are instilled into a comedy, the more the plot tends to move towards the racialized boundary. If the moral evaluation of ancestral elements (e.g., race, ethnicity, nationality etc.) is not positive, that story is no longer a comedy, which is why the racialized boundary tends to occupy no more than the space from comedy to the upper end of romance (Figure 3 ).

The cultural boundary is ambivalent as regards inclusive or exclusive boundaries of belonging; there is, though, a strong tendency towards exclusionary (i.e., rigid) social boundaries. Hence, this boundary type tends to cover only small portions of tragedy, which facilitates indefinite social boundaries, and covers a considerable share of definite boundaries (comedy and a considerable share of romance). If a cultural boundary draws its legitimacy from a community's romantically remembered cultural imaginary, it intersects with the racialized boundary. Such boundaries may enable individual boundary crossing (see the taxonomy of Wimmer, 2008, p. 1044) for "newcomers" performing a racialised majority culture, yet there is hardly room for blurring the boundary on the collective level.

Civic boundaries extend from comedy to irony. Historical events, such as the selective remembrance of the Enlightenment, impeccably represent the overlapping space of cultural and civic boundaries. If the Enlightenment past is storied as a(n) (ethno-)cultural achievement, the derived civic values are hardly separable from its healed "achievers." Ironic elements disturb such idealized/romantic portrayals of "achievers" by pinpointing "our" past failures, ambivalences, and impurities. The more ironic elements are installed into a comedy, the more the self-reflexivity and indefiniteness of the social boundary is facilitated.

\section{Method, Data and Analysis: Exploring the Turkish Issue}

Erdoğan prominently politicized matters of TurkishGerman identity and belonging on German grounds four times from 2000 onwards. These four symbolically charged events included rhetoric attacks on German au- thorities for their alleged mistreatment of Turkish immigrants (i.e., devaluation of their Turkish origin/culture). The Turkish President performed an ethno-national leader standing up for Turks on a global scale. Figure 4 illustrates his four attempts to trigger debates over cultural identity in Germany and the reactions shown by German mainstream politics (Figure 4). Hintz (2018) postulated that Erdoğan's attempts stem from his party's need to sustain identity politics, including his aim to disseminate the AKP party's core neo-Ottoman national identity narrative against secular Kemalist elites. She contends that once domestic national identity contestation was entrenched in Turkey, the AKP party extended it to the domestic-foreign policy nexus to appeal to both the domestic and the diaspora vote. Considering its population size, the Turkish diaspora in Germany was a welcome target for the Turkish President (and former Prime Minister). Turkish immigrants were granted voting rights from the 2014 Presidential Election onwards through a new policy reform. However, the puzzle is to learn when German politics was vulnerable to his conflictual politicisation attempts and to ask how the politicisation in the Great Secession period actually relates to the secessions in September 2017. These questions stream into the broader research question which explores how mainstream political actors emplot (i.e. sustain or modify) their stories in politics of Turkish-German belonging while an uprising far-right challenger party seeks to establish a far-right narrative of ethno-national rebirth.

\subsection{Case Selection: Political Context of the Turkish Issue in German Politics (2000-2017)}

Three contextual factors seemed to trigger the politicisation of the Turkish issue in Germany from September 2015 onwards: (1) German politics became vulnerable to Erdoğan's advances when, as of late-2014, the German public was prevailingly concerned with cultural identity issues (Forschungsgruppe Wahlen, 2019), (2) the German AfD party started a series of electoral successes from May 2014 onwards and transformed the core theme of its comic story from neoliberal Euroscepticism to ethno-nationalism (Özvatan \& Forchtner, 2019), and (3) media debates of the Turkish issue increased to unprecedented high scores after 2015 (Figure 5). These con-
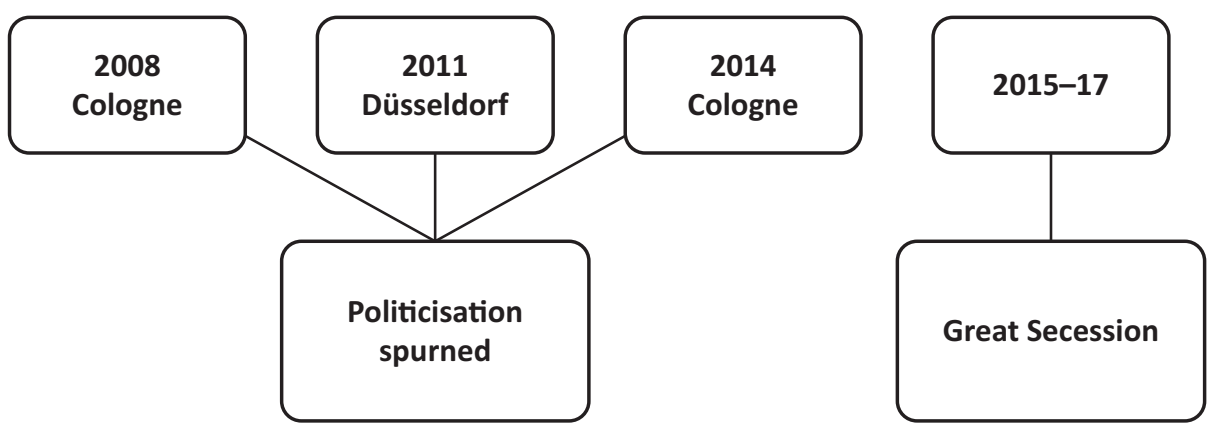

Figure 4. Four attempts at vitalising the Turkish issue (own visualisation). 
textual factors indicate that German politics became vulnerable to the politicisation of the Turkish issue after 2015. A close look at the FAZ data shows (German media discourse on the Turkish issue, see below) that the number of media articles increased from September 2015, too. Consequently, the Great Secession period from September 2015 to September 2017 is selected for an indepth case study to explore how narratives of German politics evolved over time and eventually arrived at the secessionist outcome. In September 2017, after a series of Germany-blaming by Erdoğan, consensus-oriented Angela Merkel finally broke ties with him and promised she would bring the potential of bringing EU-Turkey accession talks to a standstill to the agenda (Usta, 2017); the standstill was declared by the EU Commission in June 2018.

The media analysis of FAZ data provides a general overview of how the media discourse on the Turkish issue evolved in Germany between 2000 and 2017 (Figure 5). As salience of political issues and claims raised by political actors vary only marginally across quality newspapers in Western Europe (Koopmans, Statham, Giugni, \& Florence, 2005), data collection for the general media discourse was restricted to one mainstream quality newspaper. To reflect trends in the media discourse of the Turkish issue across time, FAZ data were inductively coded into seven macro-topics: EU-Turkey relations, foreign civic dialogue, foreign policy, foreign trade, immigrant integration party politics, immigrant integration and Turkish party politics. Macro-topics are discursive knowledge structures via which consumers of media data understand and summarise texts, i.e. media articles (van Dijk, 1991). Macro-topics which scored below an annual average of three articles or less than ten articles in a single year were excluded. Excluded macro-topics are foreign trade $(n=26)$, immigrant integration party politics $(n=38)$ and party competition in Turkey $(n=47)$.

Figure 5 illustrates that lively debates on the Turkish issue crystallized around two macro-topics between 2000 and 2008 (34 articles on annual average): acceptance of Turkey as a candidate country to the EU (EU-Turkey relations) and liberalisation of the German citizenship law (immigrant integration politics). After the general debate flattened between 2009 and 2015 (15 articles on annual average), contention between Germany and Turkey (foreign policy) peaked to a record high of 36 articles in 2016 which even almost doubled to 62 articles in 2017 (Figure 5). These numbers point to the contentious period that surrounded Erdoğan's fourth attempt at vitalising the Turkish issue in July 2016 (Figure 2).

\subsection{Research Strategy: The Processual Nature of Narrative}

Two research techniques were combined for the case study of the Great Secession period: process tracing and narrative genre analysis. Process tracing is a methodological technique for within-case analysis. Interpretivist process tracing, as a counterpart to the more established positivist process tracing, relies first and foremost on the (thick) description of events (and their interpretation) over time (Guzzini, 2012; for a general discussion of interpretivist and positivist process tracing see Bennett \& Checkel, 2014). This criterion makes it particularly suitable with narrative genre analysis of political claims because of narrative's processual character, "narrative involves movement from one structure to another" (Frye, 1957, p. 158). However, events mark an ambivalent phenomenon in narrative theory: On the one hand there is a "real" discursive event, e.g., the EU-Turkey declaration, while on the other there is the narrative backgrounding or foregrounding of that discursive event. Interpretivist process tracing is included into the analysis to account for the unfolding of "real" discursive events, which then facilitates the exploration of how narrative genres unfold in the course of these discursive events.

The combination of process tracing and narrative genre analysis thus enables a comparative analysis of three identified subsequent stages of the Great Secession with a focus on tracing how narratives (and story elements) travelled across stages in this process to secessions between Germany, the EU, Turkey and TurkishGermans. To do so, another 574 articles were gathered from quality newspapers in Germany (Süddeutsche Zeitung, 368 articles) and Turkey (Hürriyet, 206 articles) which were selected because they take comparable main-

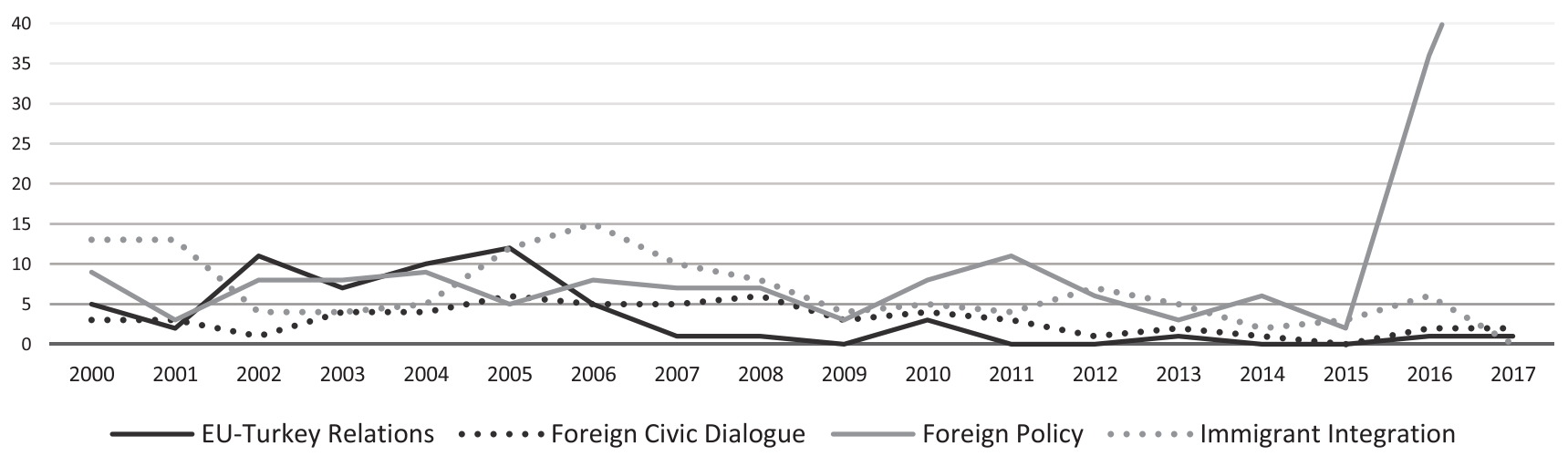

Figure 5. The Turkish issue in the German media discourse (own data collection). 
stream positions in both countries. Hence, the whole media data analysis relies on a total of 1120 quality newspaper articles in which political claims raised by political actors formed the data for narrative genre analysis.

\subsection{The Great Secession of 2015-2017}

During the Great Secession period the AfD party conveyed stories which combine far-right authoritarian and ethno-nationalist tropes with a populist style (Moffitt, 2016; Mudde, 2007): Only "the people," their supposedly homogeneous will being represented by the AfD, can guarantee cultural/racial purity, an ethno-national rebirth against self-serving and deluded elites (Özvatan \& Forchtner, 2019). Romantic racialized story elements, e.g., the Long Durée of German ethnic community, render moral authority and exigency to the idea of "saving" the German people from a "Muslim pollution threat" or, in the words of the AfD co-leader Alexander Gauland, a "creeping land grab" by Islam (Bender, 2017). This racialized comedy-romance story of the AfD crafts an ancestral pure and self-sufficient hero(ine). The high certainty of the ethno-nationally defined social boundary excludes "the other" from discourse, paving the way for communication processes to remain among "true" Germans after a promised ethno-national rebirth.

In the following, three stages of the Great Secession period are comparatively analysed with a focus on "actual" discursive events and the narrative ordering of events by political parties (i.e., mobilizing storytellers). It is described how mainstream political parties (1) (re-)tell stories of "us and them" and (2) thereby demarcate or accommodate the racialized comedy-romance story of the AfD.

\subsubsection{Stage I: Road to the EU-Turkey Migration Deal}

(September 2015-March 2016)

The civic boundary competed with the cultural boundary in this stage. The trope of a European Solution to social grievance associated with the 2015 refugee crisis imple- mented ironic elements (civic boundary; see Figure 6), which facilitated detachment from an idealized ethnonational sovereign thus facilitating debate over the inclusion of Turkish identity by pulling the comic story towards inconclusive social boundaries. The cultural boundary emerged through the implementation of romanticized cultural superiority elements. The CSU emphasized "our" cultural achievements (i.e., press freedom, freedom of speech), in response to demands by the Turkish leader Erdoğan, while the Greens and the Left party narrated similar stories (Figure 6). Other than the latter two parties, the CSU also gave particular space to ancestral elements of the national sovereign which demarcated national and European boundaries along the romanticized lines of religion, i.e., the EU as a non-Muslim club. Gerda Hasselfeldt (CSU) followed Seehofer's attempt to impede visa waivers for Turkish citizens when she added that the migration deal with Turkey must include a clause that guarantees Turkey will not become a full member of the European Union (Rossmann, 2016), which underscored the story of Europe as a non-Muslim club (Figure 6). These tropes show a proclivity to the AfD's narrative which warns "the German people" to act against a Muslim pollution threat, while the AfD's comedy-romance story is, frankly, much more racialized than the CSU story at that stage.

In October 2015, German Chancellor Merkel reiterated her call for a European solution to the European "refugee crisis" when visiting President Erdoğan. Merkel's call for a European solution reverberated with the civic boundary (Figure 6). The solution to a current humanitarian refugee crisis is not predefined along the lines of an ancestral community in her story; its solution is up for debate between political actors from within and beyond the EU willing to solve it. In this respect, Merkel's comic European Solution story blurs established social boundaries and counters an ironic irritation of the supposed self-sufficiency of the national sovereign (highlighted in grey in Figure 6).

Later, in light of the approaching EU-Turkey migration deal (which was declared on 18 March 2016), then

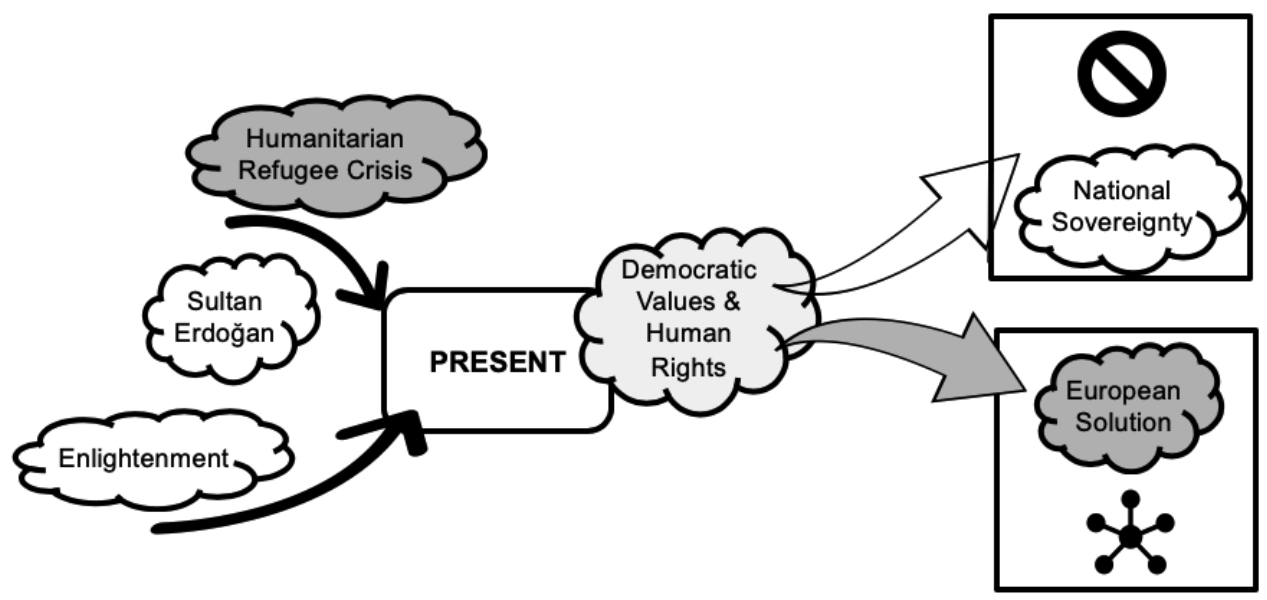

Figure 6. Comedy-romance (cultural boundary, white clouds) and comedy-irony (civic boundary, grey clouds) in Stage I. 
SPD leader Sigmar Gabriel criticized Seehofer (CSU) for stabbing Merkel in the back when demanding renewed requirements for visa liberalisation for Turkish citizens (“Gabriel: Seehofer fällt," 2016). During that period the Left and the Green party called for humanitarianism ("Drama in Idomeni, Appell an Merkel," 2016) and the CSU voiced critical stances against this deal with the Turkish leader being blamed for authoritarianism and ignoring democratic rights (Rossmann, 2016; see Figure 6). It is characteristic that the Süddeutsche Zeitung released an article entitled "Merkel's Dependence on Sultan Erdoğan" (Schlötzer, 2016). Orientalist tropes portraying Turkey as led by a "Sultan" were prominent and reverberated with cultural boundaries (Figure 6). The externalisation of anti-democratic performances and its blending with orientalism give rise to a comic story about German national sovereignty's indispensable Enlightenment past. The German hero(ine) will always stand for firm protection of ("our") domestic culture of liberal democratic values and human rights, an element which serves both endings (highlighted in lighter grey in Figure 6).

\subsubsection{Stage II: Mainstream Party Zigzag in the Post-deal} Period (April-December 2016)

In all five 2016 Federal State elections, the AfD celebrated an electoral breakthrough: the party ranked second in the Eastern and third in the Western German states (fifth in Berlin, though taking $15 \%$ of the vote share). In this stage, the cultural boundary gained momentum and the civic one diminished continuously. The cultural boundary revolved around Turkish Germans' "conflict of loyalties" between fixed notions of an "enlightened German culture" and a "non-enlightened Turkish culture." This story's cultural superiority based on "our" ancestral Enlightenment culture resembles the AfD story but is less racialized, thus less conclusive social boundaries are fostered (see Figure 7).

Once the EU-Turkey migration deal was announced, Germany-Turkey relations notably deteriorated. A satirical poem by German comedian Jan Böhmermann, which mocked Turkish President Erdoğan, developed into a diplomatic drama. Erdoğan invited Turkey's German ambassador to question why Böhmermann had not been reproached, despite Merkel describing the poem as "deliberately harmful" ("Merkel nennt Böhmermanns Erdoğan-Gedicht," 2016). Then-president of the European Parliament, Martin Schulz (SPD), responded harshly: "[We] must make it clear to Erdoğan: In our country, there is democracy" ("Schulz: "Lieber Herr Erdoğan,"' 2016). His statement perpetuated the as simplistic as dichotomising cultural boundary invoked by parts of the German mainstream already in Stage I: the Orientalist story of our legitimate democratic culture here, and their non-democratic culture there (Figure 7).

The Turkish issue heated up further in June 2016 when the German Bundestag held a non-binding vote on a resolution to formally accept the term "Armenian Genocide." The Turkish President came forward with a hard-hitting speech accusing Germany of Islamophobia and question its legitimacy, "the first country that comes to one's mind when asked about 'genocide."' (Purtul, 2016). In the same speech, he questioned Cem Özdemir's (Green party) Turkish identity, stating that his, and the other 11 Turkish German MPs' blood was "defective" (kanı bozuk), which he combined with a(n) (ethnonationalist) populist message, he alleged that they were Germany-based sleepers for anti-Turkish terror organisations directed by a global "mastermind" (üst akıl) which seeks to undermine Turkey's ethno-national resurrection. The attacked Turkish German MPs complained of receiving death threats from ultranationalist Turkish movements and individuals in Germany. Zekeriya Altuğ, a board member of the Germany-based immigrant organisation DITIB (Turkish Islamic Union for Religious Affairs), institutionally affiliated with Turkey's State Department for Religious Affairs, criticized that the attacked MPs no longer represent the Turkish German community, while other (then) board members such as Murat Kayman and Bekir Alboğa condemned the threats against the 11 attacked MPs ("Islamverband Ditib kritisiert türkeistämmige Abgeordnete," 2016). Norbert Lammert (CDU), then President of the Bundestag, reprimanded Erdoğan for attacking members of the Bundestag and thanked
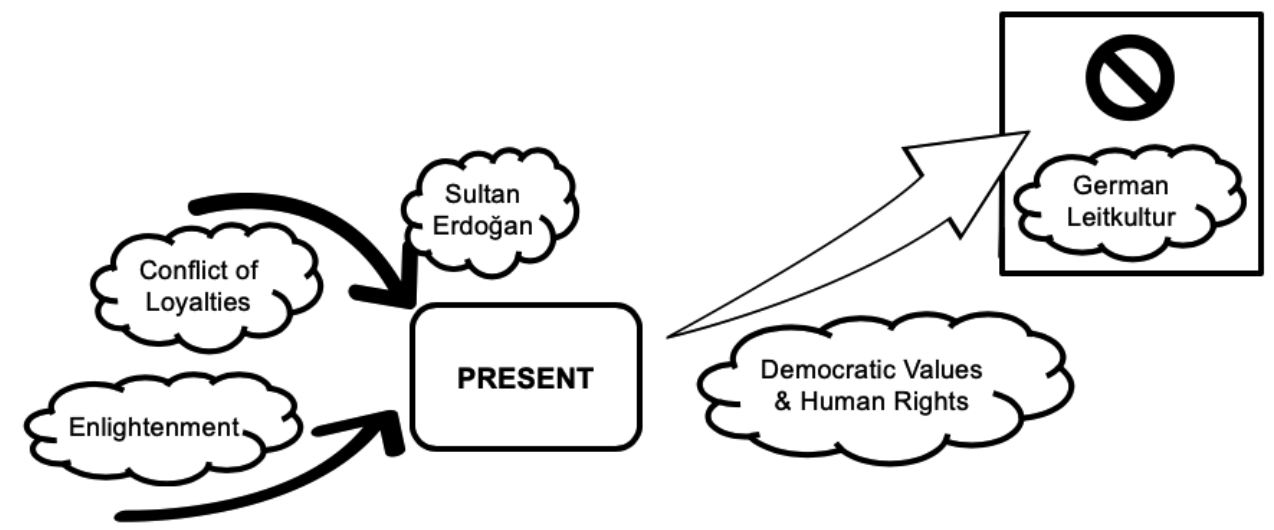

Figure 7. Comedy-romance story (cultural boundary) in Stage II. 
the Turkish Association in Berlin-Brandenburg (TBB) and the Turkish Community in Germany (TGD) for their immediate and unambiguous distancing from Erdoğan's attacks (Fried, 2016). The cultural boundary unfolded remarkably in this event: the German state authorities performed "their" Enlightenment-based German democratic culture by protecting immigrant political actors and included only those immigrant organisations into communication processes that performed their "learning" of German "Leitkultur" when distancing themselves from the Turkish Leader, "Sultan Erdoğan" (Figure 7).

After the failed coup attempt in Turkey in July 2016, the AKP party and the Union of European Turkish Democrats (hereafter UETD) organized a "democracy rally" against the coup attempt in Cologne, where Erdoğan supporters wore German and Turkish symbols and sang both national anthems. Jens Spahn (CDU) reproached Turkish-Germans' alleged disloyalty and lamented their "conflict of loyalties" ("Warnungen vor Einflussnahme der Türkei bei Demonstration in Deutschland," 2016). The discourse on "conflicts of loyalties" amplified the question: "Loyalty to which community?" On the surface level, the variation of discursive elements gave final shape to the narrative of a romantically remembered ethno-national community while the cultural and racialized boundaries shared a comedyromance storyline (see Figure 8 in Stage III). The emerging cultural boundary showed a supposed and conditional openness towards Turkish-Germans which were expected to ostensibly perform German "Leitkultur" to remove their "inner conflict" (Figure 7) or the host society will withdraw the right to belong once recognised and granted to them. The "inner conflict" discourse implemented the racialized boundary too, this being the story of a culture of ethno-national incompatibility with "our" democratic values because of "their" Ottoman ancestry. This story unfolded in the next stage and made the German political mainstream approach the ancestral ethno-national rebirth story circulated by the AfD.

\subsubsection{Stage III: The Final Curtain ahead of General} Election 2017

The final curtain showed the racialized boundary eventually enter mainstream politics, though still sharing some elements with the cultural boundary. Their nodal point crystallized around an ancestral, romanticising Enlightenment story element, which facilitates feelings of self-sufficiency and reassures the hero(ine) of "our" eminent particularity, if not greatness (Figure 8). Idealized racialized expressions of the Turkish "other" were increasingly having a heyday, alleging that the supposed anti-democratic, ancestral Ottoman culture causes "conflicts of loyalties" in Enlightenment Germany (Figure 8). A story, once initially and exclusively espoused by the far-right AfD, occupied substantial shares of mainstream narratives in the third stage.

The political context was driven by election periods both in Germany and Turkey. Besides the fastapproaching general election in September 2017, the German party system was ahead of three federal state elections. The Turkish government, itself approaching a constitutional referendum in April 2017, which would effectively concentrate more power in the hands of the president, perpetuated its demands for "the Turkish people" vis-à-vis Germany and the EU. Both party systems were thus in electoral competition mode.

After then-Prime Minister Binali Yıldırım (AKP) held a campaign event in Oberhausen, German opposition parties called for a ban on the Germany-based campaign events of the AKP which were alleged to be in support of authoritarianism and reiterated their criticism of Angela Merkel's (alleged) concessions to the Turkish president ("Yıldırım," 2017). This story perpetuated the cultural boundary proposing that Germans must eventually stand up for "their" democratic values against Turkey's (supposedly) authoritarian leader who seeks to mobilize and instil anti-democratic views in our German society: We, the enlightened German people, must oppose the import of

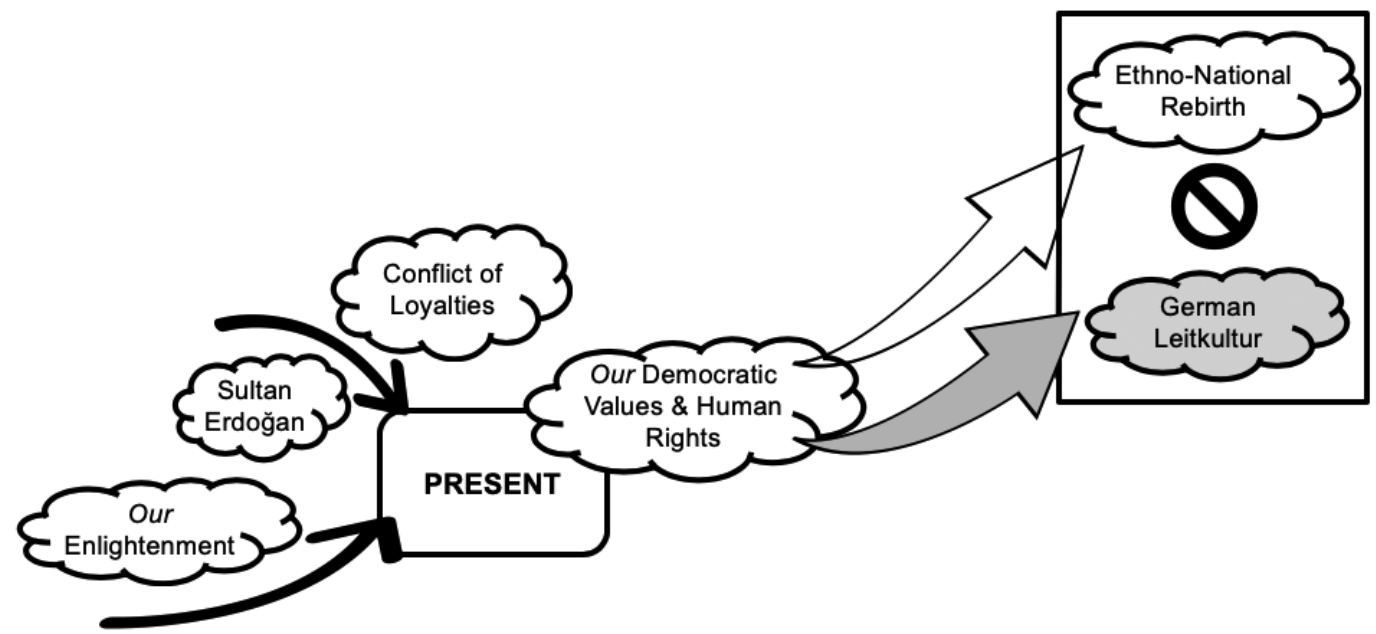

Figure 8. Stage III comedy-romance story with two happy endings, racial (white) and cultural (grey) boundaries. 
anti-democratic views and remain true to our ideals. By defining such ideals as "ours," mainstream actors mobilized claims of ancestral ownership of these values by mere Germanness, which increasingly racialized boundary elements to the comic cultural boundary story.

That became apparent in March 2017 when German municipalities blocked AKP campaign events, which made Erdoğan contend that "if I want to, I will come to Germany" and blame the German authorities for "Nazi practices" (Bielicki, Hickmann, \& Szymanski, 2017). In mid-August, Erdoğan invited Turkish Germans to protest against the Green, CDU and SPD parties in the upcoming general election because they were "hostile to Turkey" ("Bundestagswahl," 2017; Usta, 2017). In turn, Merkel questioned whether, under these impairing circumstances, the EU should extend the Customs Union with Turkey after twenty years of its existence (Fried, 2017). Eventually, in the pre-election TV debate (3 September 2017), Merkel and Schulz engaged in competitive zeal to demonstrate who could adopt a stricter stance against Erdoğan, once (re-)elected, in the name of our democracy; and they both resolutely called for a cancellation of EU-Turkey accession talks (Brössler, 2017). Even Merkel, who invoked a comedy-irony story (civic boundary) in Stage I, now resorted to a comedy-romance (cultural boundary) which circulated a vision of "us" as the enlightened people who own democratic values and, ultimately, resulted in ethno-nationally secessionist politics in German politics' Turkish issue (Figure 8).

\section{Conclusion}

How did the German mainstream parties emplot their stories in the Great Secession period vis-à-vis a rising farright contender? Substantial shares of mainstream political parties adapted the AfD's racialized comedy-romance story, which suggests that the story and the AfD party as a mobilizing storyteller have been legitimized in the political centre. In the first stage of the Great Secession, the inclusionary civic boundary competed with the rather exclusionary cultural boundary. As such, story elements of "our" cultural superiority based on "our" ethno-national community's Enlightenment past spread within the mainstream and increasingly instilled elements of the AfD's ancestral romanticism (i.e., ethno-national destiny) in subsequent stages. In this context, comedies with ironic elements which disseminate inconclusive social boundaries, such as Merkel's European Solution story, phased out. It is unsurprising then that the discursive space for accommodating the complexity and diversity of TurkishGerman belonging happened to shrink, and a secessionist outcome to appear, when narratives of an ancestral neo-Ottoman revival in Turkey and of ethno-national rebirth in German politics made up leeway.

Building on a revised storytelling approach to Habermasian communicative action theory, this article has sought to explore the opening and blocking of communication processes (of social boundaries) in the politics of Turkish-German belonging. The analysis indicates that the political centre took steps towards rigid ethno-cultural boundaries between "Germans" and "Turks." However, even if mainstream political parties merely intended to adapt far-right positions as a shortterm strategy to regain disenchanted voters, the unintended effect is that the powerful unfolding of a narrative genre is triggered. If the comic story conveys an idealized ethno-nationally pure hero(ine) and audiences have associated feelings, popular mobilisation gains a hardly stoppable momentum. That is, once the audience "buys" the comedy-romance story, it is hard to escape those feelings because reversed rational arguments suggest so. Incentives to include "the other's" perspective in reflection and argumentation are hampered; communication is restricted to flow within our taken-forgranted echo chambers. In fact, with the ascent of racialized comedy-romances, both the communication of inconclusive boundaries (e.g., Merkel's European Solution story in Stage I) and the presence of diversities and complexities of Turkish-German belonging (e.g., reactions to Armenian Genocide resolution in Stage II) disappear over time. Inclusion of Turkish-German perspectives emerged only after ostentatious performances of German "Leitkultur," which was welcomed as a clearcut decision for loyalty to Germany instead of Turkey by German authorities.

Further, it became apparent in the analysis that the Enlightenment past embodies a seminal cultural repertoire in German political culture. The romanticized transmission and ancestral roots restrict this cultural repertoire to a world of "idealized existence" of a German ethno-national community. Tragic and ironic extensions to comedy are blocked, pure comedies or comedies pushing for romanticism are facilitated. Hence, this cultural repertoire feeds into cultural boundaries and racialized boundaries due to its ancestral purification of the ethnonational German hero(ine). The community mobilising around such a hero(ine) derives its cultural and/or ethnoracial commonality from an idealized remembrance of a past achievement which is hard to affirm by "newcomers": They may perform it on the individual level, yet have no legitimate right of shared ownership or membership on the collective level. Not only is ethnocultural and ethno-racial difference created through the Enlightenment cultural repertoire, but feelings of cultural or racial superiority are also fostered through that idealized and particularizing remembrance of the Enlightenment past.

Given the identified adaptation of far-right narratives of "ethno-national rebirth" story, what are the avenues for future research? To begin with, comparative research may explore whether the identified adaptation is able to travel globally across cases in time and space. Secondly, this article's transnational agenda is open to extension. That is, to historically, and more systematically, assess the possible effects of Turkey's nostalgic return to neo-Ottoman identity on stories of Turkish-German be- 
longing. A case in point is marked by an October 2015 image of the meeting between Merkel and Erdoğan in Turkey's then newly-built presidential palace. Its iconography made western European media immediately signify a "Sultan." Beyond orientalist demarcation by "the West," such images may be associated with authority and strength by some members of the in-group, while others may fear a turn to ancestral backwardness (e.g., autocracy). In this context, a fine-grained focus (ethnographic) research of the narrative (genre) organisation of belonging among the diverse strings of Turkish immigrant associations and movements in Germany poses an interesting avenue for future research in this field. Finally, yet another puzzle deserving of further study is "gendered storytelling." For instance, the theorising of the prevalent gendered romantic trope, "a fairy-tale princess kisses a frog prince for a happy ending" into the analysis of politics of belonging seems essential. A gendered storytelling approach might certainly ameliorate our understanding of the politics of Turkish-German belonging by asking: Who was the frog prince(ss) in the Great Secession drama? What were the gendered cultural repertoires that were disseminated?

\section{Acknowledgments}

I am grateful to Bernhard Forchtner and Seyran Bostancl, the three reviewers and all commentators to prior versions of this article at, e.g., the 2018 ECPR Conference in Hamburg, the 2019 CES Conference in Madrid and the "The New Right and the New Left" workshop in 2018 at the London School for Economics and Political Science for their valuable suggestions. Last but not least, I owe special thanks to Laura Schlagheck for her excellent research assistance. All mistakes remain my own.

\section{Conflict of Interests}

The author declares no conflict of interests.

\section{References}

Akkerman, T., de Lange, S. L., \& Rooduijn, M. (2016). Inclusion and mainstreaming? Radical right-wing populist parties in the new millennium. In T. Akkerman, S. L. de Lange, \& M. Rooduijn (Eds.), Radical right-wing populist parties in Western Europe: Into the mainstream? (pp. 1-28). London: Routledge.

Alba, R. (2005). Bright vs. blurred boundaries: Secondgeneration assimilation and exclusion in France, Germany, and the United States. Ethnic and Racial Studies, 28(1), 20-49.

Alexander, J. (2004). Cultural pragmatics: Social performance between ritual and strategy. Sociological Theory, 22(4), 527-573.

Anderson, B. (1983). Imagined communities: Reflections on the origin and spread of nationalism. London: Verso.
Barth, F. (1969). Ethnic groups and boundaries: The social organisation of culture difference. Long Grove, IL: Waveland Press.

Bauman, Z. (1991). Modernity and ambivalence. Cambridge: Polity Press.

Bender, J. (2017, August 28). AfD teilt aus. Gauland: Özoğuz in Anatolien entsorgen [AfD deals out. Gauland: Discard Özoğuz in Anatolia]. Frankfurter Allgemeine Zeitung. Retrieved from https://www.faz. net/aktuell/politik/bundestagswahl/afd-alexandergauland-traeumt-von-entsorgung-aydan-oezoguz15171141.html

Bennett, A., \& Checkel, J. T. (Eds.). (2014). Process tracing: From metaphor to analytic tool (strategies for social inquiry). Cambridge: Cambridge University Press.

Bielicki, J., Hickmann, C., \& Szymanski, M. (2017, March 6). Erdoğan wirft Berlin Nazi-Praktiken vor [Erdoğan accuses Berlin of Nazi practices.] Süddeutsche Zeitung.

Brössler, D. (2017, September 8). Berlin mit TürkeiPlänen in der EU isoliert [Berlin's Turkey-Plans isolated within the EU]. Süddeutsche Zeitung.

Bruner, J. (2004). Life as narrative. Social Research: An International Quarterly, 71(3), 691-710.

Bundestagswahl: Erdoğan ruft zu Wahlboykott von CDU, SPD und Grünen auf [National election: Erdoğan calls for boycott of CDU, SPD and the Greens]. (2017, August 19). Frankfurter Allgemeine Zeitung. Retrieved from https://www.faz.net/1.5157235

Choo, H. Y., \& Ferree, M. M. (2010). Practicing intersectionality in sociological research: A critical analysis of inclusions, interactions, and institutions in the study of inequalities. Sociological Theory, 28, 129-149.

Dancygier, R., \& Margalit, Y. (2019). The evolution of the immigration debate: Evidence from a new dataset of party positions over the last half-century. Comparative Political Studies, 53(5). https://doi.org/10.1177/ 0010414019858936

Douglas, M. (1966). Purity and danger: An analysis of concept of pollution and taboo. London and New York, NY: Routledge.

Drama in Idomeni, Appell an Merkel [Drama in Idomeni, appeal to Merkel]. (2016, March 7). Süddeutsche Zeitung.

Engelken Jorge, M., Forchtner, B., Özvatan, Ö., \& Eder, K. (2019). From storytelling to collective learning: The making of inclusionary and exclusionary populism. Manuscript submitted for publication.

Forchtner, B. (2016). Lessons from the past? Memory, narrativity and subjectivity. London: Palgrave Macmillan.

Forchtner, B., Engelken Jorge, M., \& Eder, K. (2018). Towards a revised theory of collective learning processes: Argumentation, narrative and the making of the social bond. European Journal of Social Theory. Advance online publication. https://doi.org/ $10.1177 / 1368431018814348$

Forschungsgruppe Wahlen. (2019). Politbarometer: 
"Wichtige Probleme in Deutschland seit 2000" and "Pojektion Wahlpräferenz" [Politbarometer: "Important problems in Germany since 2000" and "projection of voting preference"]. Retrieved from https://www.forschungsgruppe.de/Umfragen/ Politbarometer/Langzeitentwicklung_-_Themen_ im_Ueberblick

Fried, N. (2016, June 10). Lammert weist Erdoğan zurecht, Merkel applaudiert [Lammert reprimands Erdoğan, Merkel applaudes]. Süddeutsche Zeitung.

Fried, N. (2017, August 30). Merkel will Zollunion mit der Türkei blockieren [Merkel wants to block customs union with Turkey]. Süddeutsche Zeitung.

Frye, N. (1957). Anatomy of criticism: Four essays. Princeton, NJ: Princeton University Press.

Gabriel: Seehofer fällt Merkel in den Rücken [Gabriel: Seehofer stabs Merkel in the back]. (2016, March 15). Süddeutsche Zeitung. Retrieved from https:// www.sueddeutsche.de/politik/grosse-koalitiongabriel-seehofer-faellt-merkel-in-den-ruecken1.2909177

Guzzini, S. (Ed.). (2012). The return of geopolitics in Europe? Social mechanisms and foreign policy identity crises. Cambridge: Cambridge University Press.

Habermas, J. (1981). Theorie des Kommunikativen Handelns [The theory of communicative action]. Frankfurt: Suhrkamp.

Habermas, J. (1998). The inclusion of the other: Studies in political theory. Cambridge, MA: MIT Press.

Hall, S. (1996). Introduction: Who needs 'identity'? In S. Hall \& P. Gay (Eds.), Questions of cultural identity (pp. 1-17). London: SAGE Publications.

Hall, P., \& Lamont, M. (2013). Why social relations matter for politics and successful societies. Annual Review of Political Science, 16, 49-71.

Hecking, C. (2013, August 1). Britische Geheimprotokolle. Kohl wollte offenbar jeden zweiten Türken loswerden [British secret documents. Obviously Kohl wanted to get rid of one in two Turks]. Der Spiegel.

Hintz, L. (2018). Identity politics inside out: National identity contestation and foreign policy in Turkey. New York, NY: Oxford University Press.

Islamverband Ditib kritisiert türkeistämmige Abgeordnete [Islamic association Ditib criticizes Turkish origin parlamentarians]. (2016, June 13). Süddeutsche Zeitung.

Jacobs, R., \& Smith, P. (1997). Romance, irony, and solidarity. Sociological Theory, 15(1), 60-80.

Kaya, A. (2018). Turkish origin migrants and their descendants: Hyphenated identities in transnational space. London: Palgrave.

Koopmans, R., Statham, P., Giugni, M., \& Florence, P. (2005). Contested citizenship: Immigration and cultural diversity in Europe (Vol. 25). Minneapolis, MN: University of Minnesota Press.

Korteweg, A., \& Yurdakul, G. (2014). The headscarf debates: Conflicts of national belonging. Stanford, CA: Stanford University Press.
Lamont, M., \& Molnár, V. (2002). The study of boundaries in the social sciences. Annual Review of Sociology, 28, 167-195.

Mandel, R. (2008). Cosmopolitan anxieties: Turkish challenges to citizenship and belonging in Germany. Durham, NC: Duke University Press.

Merkel nennt Böhmermanns Erdoğan-Gedicht "bewusst verletzend" [Merkel calls Böhmermann's Erdoğan poem "deliberately harmful"]. (2016, April 4). Süddeutsche Zeitung.

Moffitt, B. (2016). The global rise of populism: Performance, political style, and representation. Stanford, CA: Stanford University Press.

Mudde, C. (2007). Populist radical right parties in Europe. Cambridge: Cambridge University Press.

Neumann, I. (1999). Uses of the other: "The East" in European identity formation. Minneapolis, MN: University of Minnesota Press.

Özvatan, Ö., \& Forchtner, B. (2019). Towards a 'happy ending'? The far right in Germany. In A. Waring (Ed.), The new authoritarianism: A risk analysis of the altright (pp. 199-226). Hannover: ibidem.

Purtul, B. (2016, June 4). "Eyyy Almanya derdin ne?" ["Hey Germany, what is your problem?"]. Hürriyet.

Quent, M. (2019). Deutschland Rechtsaußen. Wie die Rechten nach der Macht greifen und wie wir sie stoppen können [Germany far right. How the Right grabs for power and how we can stop them]. München: Piper.

Rossmann, R. (2016, March 16). Ein widerborstiges Ja [A cross-grained yes]. Süddeutsche Zeitung.

Schlötzer, C. (2016, January 22). Merkels Abhängigkeit von Sultan Erdoğan [Merkel's dependence on Sultan Erdoğan]. Süddeutsche Zeitung. Retrieved from https://www.sueddeutsche.de/politik/tuerkei-einheikler-partner-1.2829768

Somers, M. R. (1994). The narrative constitution of identity: A relational and network approach. Theory and Society, 23(5), 605-649.

Schulz: "Lieber Herr Erdoğan, Sie sind einen Schritt zu weit gegangen" [Schulz: "Dear Mister Erdoğan, you have gone one step too far"]. (2016, April 3). Süddeutsche Zeitung.

Toolan, M. J. (1988). Narrative: A critical linguistic introduction. London: Routledge.

Usta, B. (2017, August 18). Erdogan tells Turks in Germany to vote against Merkel. Reuters. Retrieved from https://www.reuters.com/article/us-germanyturkey/erdogan-tells-turks-in-germany-to-voteagainst-merkel-idUSKCN1AY17Z

van Dijk, T. (1991): The interdisciplinary study of news as discourse. In K. Bruhn-Jensen \& N. Jankowksi (Eds.), Handbook of qualitative methods in mass communication research (pp. 108-120). Abingdon: Routledge.

van Kessel, S. (2015). Populist parties in Europe. London: Palgrave Macmillan.

van Spanje, J. (2010). Contagious parties: Antiimmigration parties and their impact on other 
parties' immigration stances in contemporary Western Europe. Party Politics, 16, 563-586.

Wagner-Pacifici, R. (1986). The Moro morality play: Terrorism as social drama. Chicago, IL: University of Chicago Press.

Warnungen vor Einflussnahme der Türkei bei Demonstration in Deutschland" [Warning of Turkey's influence at rally in Germany]. (2016, July 30). Süddeutsche Zeitung.

White, H. V. (1973). Metahistory: The historical imagination in nineteenth-century Europe. Baltimore, MD:
Johns Hopkins University Press.

Wimmer, A. (2013). Ethnic boundary making: Institutions, power, networks. Oxford: Oxford University Press.

Wimmer, A. (2008). Elementary strategies of ethnic boundary making. Ethnic and Racial Studies, 31(6), 1025-1055.

Yıldırım: "Seid ihr bereit für eine mächtige Türkei?" [Yıldırım: "Are you ready for a mighty Turkey?"]. (2017, February 18). Süddeutsche Zeitung.

Yuval-Davis, N. (2011). The politics of belonging: Intersectional contestations. London: SAGE Publications.

\section{About the Author}

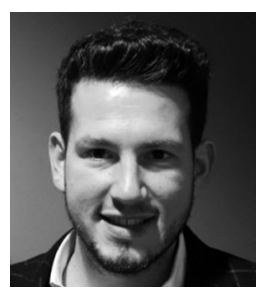

Özgür Özvatan is a Research Cluster Coordinator at the Berlin Institute for Integration and Migration Research, Humboldt University of Berlin. He is a PhD Candidate in the International Doctoral Program of the Berlin Graduate School of Social Sciences (BGSS), currently Visiting Fellow at the School of Social and Political Science at the University of Melbourne, and a Doctoral Fellow with the Centre for Analysis of the Radical Right (CARR). Özgür's research is based in the field of political sociology covering the politics of (non-)belonging, the mainstreaming of the far right and immigrant political identities. 